\title{
Nutritional value of organic acid lime juice (Citrus latifolia T.), cv. Tahiti
}

\author{
Valor nutricional de lima ácida (Citrus latifolia T.), cv. Thaiti
}

Carolina Netto RANGEL ${ }^{1}$, Lucia Maria Jaeger de CARVALHO ${ }^{2 *}$, Renata Borchetta Fernandes FONSECA ${ }^{3}$, Antonio Gomes SOARES ${ }^{4}$, Edgar Oliveira de JESUS 5

\begin{abstract}
Acid lime can be used as fresh fruit or as juice to increase the flavor of drinks. Therefore, it is necessary to analyze organic acid lime nutritional composition in order to evaluate if there are important differences among those conventionally produced. No significant differences in total titrable acidity, $\mathrm{pH}$, ascorbic acid, sucrose, calcium, and zinc were found between the acid lime juice from organic biodynamic crops and conventional crops. However, the organic biodynamic fruits presented higher peel percentage than the conventional ones leading to lower juice yield. On the other hand, fructose, glucose, total soluble solids contents, potassium, manganese, iron, and copper were higher in the conventional samples. These results indicated few nutritional differences between organic and conventional acid lime juices in some constituents. Nevertheless, fruit juice from biodynamic crops could be a good choice since it is free from pesticides and other agents that cause problems to human health maintaining the levels similar to those of important nutritional compounds.

Keywords: physical and chemical composition; fruit juice; organic crops; Citrus latifolia.
\end{abstract}

\section{Resumo}

A lima ácida pode ser utilizada sob a forma in natura, como suco e para agregar sabor a bebidas. Portanto, é necessário avaliar diferenças na composição nutricional entre limas provenientes de cultivos orgânicos e convencionais. Não foram encontradas diferenças significativas na acidez titulável total, $\mathrm{pH}$, ácido ascórbico, sacarose, cálcio e zinco. Entretanto, os frutos orgânicos biodinâmicos apresentaram maior percentual de cascas e menor rendimento de suco do que os frutos convencionais. Por outro lado, os teores de frutose, glicose, sólidos solúveis totais, potássio, manganês, ferro e cobre foram mais elevados nos frutos orgânicos do que nos convencionais. Estes resultados indicam que existem poucas diferenças nutricionais entre limas ácidas convencionais e orgânicas biodinâmicas. Entretanto, os sucos provenientes de cultivo biodinâmico podem ser uma boa alternativa para escolha tendo em vista serem livres de pesticidas e outros agentes tóxicos, que podem causar danos à saúde humana, mantendo níveis próximos de importantes compostos nutricionais.

Palavras-chave: composição físico-química; suco de fruta; cultivos orgânicos; Citrus latifolia.

\section{Introduction}

Today, a significant increase in organic food consumption has been observed in some countries in the world. Population lifestyle and environmental issues are important factors to explain such increase and must be taken into consideration when production and market strategies are developed (GIL; GRACIA; SÁNCHEZ, 2000). On the other hand, studies have shown that personal factors such as health and food flavor are considered more important by a significant number of organic food consumers than other factors such as environmental preservation, (INTERNATIONAL..., 2005). Biodynamic agriculture, the purest form of organic agriculture, is based on the spiritual understanding of nature, holistic approach, and practice (REIJNTJES; HAVERKORT; WATERS-BAYER, 1994; SOCIEDADE..., 2005). Biodynamic chemical preparations are certified and monitored with accreditation recognized worldwide (STRINGHETA; MUNIZ, 2003).

Fruit quality and composition depends of pre- and postharvest factors, and these factors can affect their nutritional, sensorial, and technological characteristics (MORILLAS RUIZ, 2005; CHINNICI et al., 2005; GARCÍA-SANCHEZ et al., 2003).

Acid lime fruits (Citrus latifolia Tanaka) are grown almost exclusively in tropical climates. Brazil is one of the most important producers. Acid limes are used as fresh fruit or as juice especially as a blend component added to increase drink flavor (FOOD..., 2003).

The objective of the present study was to evaluate the contents of ascorbic acid, minerals, sugars, total soluble 
solids, $\mathrm{pH}$, titrable acidity, and juice yield of the acid lime juice, cv. Tahiti, from conventional and organic biodynamic production systems.

\section{Material and methods}

\subsection{Raw material}

Nineteen kilograms of acid lime (Citrus latifolia Tanaka.), cv. Tahiti, from a conventional production system, cultivated in São Paulo and purchased at the Central de Abastecimento do Estado da Guanabara (CADEG), a farmers' market in Rio de Janeiro, and $18 \mathrm{~kg}$ of organic biodynamic acid lime (Citrus latifolia Tanaka), cv. Tahiti, supplied by Bom Jesus Farm, São Paulo, Brazil were used. The acid lime fruits were harvested in May/June 2005.

\subsection{Experimental design and statistical analyses}

The fruits were coded as: CL (conventional acid lime) and BL (biodynamic acid lime). Each group was sorted into 5 lots with 10 samples per lot. All analyses were carried out in triplicate. The CL lot had around $3.8 \mathrm{~kg}$ and the BL lot around $3.6 \mathrm{~kg}$ of acid lime. All data were treated by analysis of variance (ANOVA). The comparison among the treatment averages was made using the Least Significance Difference test (LSD) at the level of $5 \%$ of probability. All statistical analyses were carried out using Statistica software version 5.1.

\subsection{Acid lime juice processing}

The raw material was selected, weighed, and washed to remove the soil residues, and the sample sanitized by immersion in chlorinated water, $100 \mathrm{mg} . \mathrm{L}^{-1}$, for 10 minutes. The acid lime juice was extracted using a multiprocessor (Wallita) coupled with a finisher to remove the pulp. The fruit juice was conditioned in identified PVC containers and stored under freezing at $-10{ }^{\circ} \mathrm{C}$ for 2 weeks.

\subsection{Acid lime juice yield}

The yield of both experimental groups (CL and $\mathrm{BL}$ ) was calculated by the ratio of total fruit weight and final juice weight.

\subsection{Total titrable acidity and $\mathrm{pH}$}

The $\mathrm{pH}$ and total titrable acidity were determined using a potentiometric titration equipment (Metrohn 798MPT Titrino) in accordance with ISO 750:1998 (E) method (INTERNATIONAL..., 1998).

\subsection{Total soluble solids $\left({ }^{\circ}\right.$ Brix $)$}

Total soluble solids ( ${ }^{\circ} \mathrm{Brix}$ ) were measured using an Atago TR 101 refractometer at $20{ }^{\circ} \mathrm{C}$ (ISO 2173:1978 - E) (INTERNATIONAL..., 1978).

\subsection{Vitamin C (ascorbic acid)}

Vitamin C content was determined by high-performance liquid chromatography (HPLC) using an Alliance chromatograph coupled with BioRad HPX87H column, UV/visible detector, sulfuric acid $0.1 \mathrm{~N}$ as mobile phase, and a $0.7 \mathrm{~mL} /$ minutes flow. The sample preparation performed with $2.5 \mathrm{~g}$ of acid lime juice, diluted with sulfuric acid $0.1 \mathrm{~N}$, and ultrasonicated for 10 minutes. The volume was completed to $25 \mathrm{~mL}$ with sulfuric acid $0.1 \mathrm{~N}$ in a volumetric flask, filtered in a Wathman $\mathrm{n}^{\circ} .1$ filter, stored in glass flasks, and kept at $-18^{\circ} \mathrm{C}$. Vitamin C quantification was performed by injecting $20 \mu \mathrm{g} \cdot \mathrm{mL}^{-1}$ of ascorbic acid standard solution (number A92902, Sigma-Aldrich) (ASSOCIATION..., 2005).

\subsection{Soluble sugars (fructose, glucose and sucrose)}

Soluble sugars were quantified by high-performance liquid chromatography (HPLC). The Alliance HPLC system was used coupled with a Waters 044355 reversed-phase column and a refractive index detector. The mobile phase consisted of Milli Q water/acetonitrile 25:75 at a flow rate of $1 \mathrm{~mL} /$ minute. Standards for quantification included fructose, glucose, and sucrose (0.05 g.mL $\mathrm{mL}^{-1}$ each), which were from Sigma-Aldrich $\left(\mathrm{n}^{\circ} .47748,47289\right.$, and 47249 , respectively). Around $1.0 \mathrm{~g}$ of acid lime juice samples were added to $5 \mathrm{~mL}$ of Milli $\mathrm{Q}$ water and treated with ultrasound for 20 minutes, followed by the addition of $5 \mathrm{~mL}$ of acetonitrile, and the final volume was completed with Milli Q water up to $25 \mathrm{~mL}$. All samples were filtered using Wathman $\mathrm{n}^{\circ} .1$ filter, stored in glass flasks and maintained at $-18^{\circ} \mathrm{C}$ (ASSOCIATION..., 2005).

\subsection{Minerals}

The minerals were measured using the $\mu$-Synchrotron Radiation Excited X ray Fluorescence microprobe (TXRF) from the National Laboratory of Light Synchrotron, Campinas - São Paulo. Each sample was prepared from an aliquot of $500 \mathrm{~mL}$ of acid lime juice. The samples were digested with acid nitric $\left(\mathrm{HNO}_{3}\right)$ $65 \%$ (Merck) and hydrogen peroxide $\mathrm{H}_{2} \mathrm{O}_{2} 30 \%$ (Merck) under $60{ }^{\circ} \mathrm{C}$ heating for 6 hours. $50 \mu \mathrm{L}$ of gallium solution $\left(102 \mu \mathrm{g} \cdot \mathrm{g}^{-1}\right)$ was then added as internal standard to an aliquot of $500 \mu \mathrm{L}$ of acid lime juice. An aliquot of $8 \mu \mathrm{L}$ was transferred to the Lucite reflecting support placed under infrared light to be dehydrated. This support was placed horizontally to the high pure germanium detector (HPGe) - with resolution of $140 \mathrm{eV}$ in $5.9 \mathrm{keV}$, and the aliquot was excited with a white beam of irradiation with maximum energy of $20 \mathrm{keV}$. The excited aliquot was filtered through of $0.5 \mathrm{~mm}$ of aluminum at an incidence angle of $1.0 \mathrm{mrad}$. The sample and standard measuring time was 100 seconds, and the characteristic $\mathrm{X}$ ray specters obtained were analyzed with the software X rays Quantitative Analysis System (AXIL) [192], distributed by the Atomic International Energy Agency (AIEA). The $\mathrm{X}$ ray intensities were collected for each element and associated with error data probability. The analyses were carried out using three replicates, and the $\mathrm{HNO}_{3} 65 \%$ and $\mathrm{H}_{2} \mathrm{O}_{2}$ $30 \%$ solution was used as blank sample (ASSOCIATION..., 2005)

\section{Results and discussion}

\subsection{Acid lime juice yield}

The acid lime juice yields of the conventional method (CL) and biodynamic method (BL) were $56.0 \%( \pm 1.22)$ and $44.2 \%$ 
( \pm 3.43$)$, respectively. Table 1 shows that the CL juice yield was significantly higher than the BL juice yield.

This significant difference was probably due to the higher percentage of fruit peel in the biodynamic fruits $(49.2 \% \pm 2.70)$ than in the conventional ones $(40.6 \% \pm 2.31)$, which may decrease total juice volume (Table 1). The fertilizer level used can influence citrus quality. According to Chitarra and Chitarra (1990), some minerals such as potassium, magnesium, and zinc applied in the soil to increase fruit size and weight.

Fruit juice yield can be reduced by applying high concentrations of nitrogen and potassium in the soil, thus increasing peel thickness. The relative humidity and temperature of the environment can also influence peel thickness in citrus (CHITARRA; CHITARRA, 1990).

\subsection{Total soluble solids, total acidity, and $\mathrm{pH}$}

The results of total titrable acidity were $6.05 \pm 0.157$ for CL samples and $5.98 \pm 0.502$ for BL samples. Soluble solids were $8.42 \pm 0.89$ and $7.63 \pm 0.379$ for CL and BL samples, respectively. These results agree with those observed by Marin et al. (2002) obtained for the varieties Fino and Verna. The fruit juice $\mathrm{pH}$ was $2.81 \pm 0.011$ and $2.78 \pm 0.044$ for CL and BL samples, respectively. The statistical analyses indicated no significant differences between $\mathrm{CL}$ and $\mathrm{BL}$ fruit juices for total titrable acidity and $\mathrm{pH}$; however, the soluble solids content of the $\mathrm{BL}$ group was lower than that of the CL group (Table 1).

Fruit composition and aroma can be modified by sunlight intensity and pesticide use (MATTHEIS; FELLMAN, 1999). The intense sun's rays the fruit receives can influence total soluble solids but not total titrable acidity. Phosphorus fertilization leads to a reduction of total acidity and soluble solids (CHITARRA; CHITARRA, 1990).

The organic acid and sugars in fruit juice are very important. Fruit juice ratio is the relation between ${ }^{\circ}$ Brix and acidity. Significant differences in juice fruit ratio can affect its chemical and sensorial characteristics. Therefore, this information is crucial for technological process optimization and fruit juice acceptance by consumers (MATTHEIS; FELLMAN, 1999; CHINNICI et al., 2005; MARSH et al., 2006).

Total titrable acidity of both groups was found to comply with the Brazilian Identity and Quality Standard legislation that determines a minimum of $5 \mathrm{~g} .100 \mathrm{~g}^{-1}$ in citric acid for acid lime juices. In addition, total titrable acidity content, solid soluble, and $\mathrm{pH}$ values were very similar to those found in a previous study carried out by Pedrão et al. (1999).

\subsection{Vitamin C (ascorbic acid)}

The ascorbic acid contents were $22.86 \pm 0.426$ and $22.80 \pm 2.084$ for CL and BL fruit juices, respectively. No significant difference was observed between CL and BL fruit juice samples (Table 1). These results are also in accordance with the Brazilian Identity and Quality Standard (BRASIL, 2000) that determines a minimum of $20.0 \mathrm{mg} .100 \mathrm{~g}^{-1}$ for ascorbic acid in acid lime juice.
Table 1. Conventional and biodynamic acid lime juice composition.

\begin{tabular}{lcc}
\hline & CL & BL \\
\hline pH & $2.81^{\mathrm{a}}( \pm 0.011)$ & $2.78^{\mathrm{a}}( \pm 0.044)$ \\
Acidity $\left(\mathrm{g} .100 \mathrm{~g}^{-1}\right.$ citric acid $)$ & $6.05^{\mathrm{a}}( \pm 0.157)$ & $5.98^{\mathrm{a}}( \pm 0.502)$ \\
Soluble solids $\left({ }^{\circ} \mathrm{Brix}\right)$ & $8.42^{\mathrm{a}}( \pm 0.189)$ & $7.63^{\mathrm{b}}( \pm 0.379)$ \\
Vitamin C $\left(\mathrm{mg} .100 \mathrm{~mL}^{-1}\right)$ & $22.86^{\mathrm{a}}( \pm 0.426)$ & $22.80^{\mathrm{a}}( \pm 2.084)$ \\
Fructose $\left(\mathrm{g} .100 \mathrm{~g}^{-1}\right)$ & $0.98^{\mathrm{a}}( \pm 0.100)$ & $0.66^{\mathrm{b}}( \pm 0.058)$ \\
Glucose $\left(\mathrm{g} .100 \mathrm{~g} \mathrm{~g}^{-1}\right)$ & $0.89^{\mathrm{a}}( \pm 0.051)$ & $0.54^{\mathrm{b}}( \pm 0.053)$ \\
Sucrose $\left(\mathrm{g} .100 \mathrm{~g}^{-1}\right)$ & $0.07^{\mathrm{a}}( \pm 0.058)$ & $0.12^{\mathrm{a}}( \pm 0.021)$ \\
$\mathrm{K}\left(\mu \mathrm{g} \cdot \mathrm{g}^{-1}\right)$ & $376.79^{\mathrm{a}}( \pm 33.270)$ & $240.70^{\mathrm{b}}( \pm 17.112)$ \\
$\mathrm{Ca}\left(\mu \mathrm{g} \cdot \mathrm{g}^{-1}\right)$ & $23.24^{\mathrm{a}}( \pm 0.693)$ & $23.41^{\mathrm{a}}( \pm 0.856)$ \\
$\mathrm{Mn}\left(\mu \mathrm{g} \cdot \mathrm{g}^{-1}\right)$ & $0.08^{\mathrm{a}}( \pm 0.004)$ & $0.04^{\mathrm{b}}( \pm 0.000)$ \\
Fe $\left(\mu \mathrm{g} \cdot \mathrm{g}^{-1}\right)$ & $1.71^{\mathrm{a}}( \pm 0.078)$ & $0.75^{\mathrm{b}}( \pm 0.134)$ \\
Cu $\left(\mu \mathrm{g} \cdot \mathrm{g}^{-1}\right)$ & $0.35^{\mathrm{a}}( \pm 0.014)$ & $0.20^{\mathrm{b}}( \pm 0.007)$ \\
Zn $\left(\mu \mathrm{g} . \mathrm{g}^{-1}\right)$ & $0.29^{\mathrm{a}}( \pm 0.064)$ & $0.43^{\mathrm{a}}( \pm 0.014)$ \\
\hline Same letters in the same column present no statistical differences for LSD test $(\mathrm{p}<0.05)$. \\
LC - conventional acid lime juice; LB - biodynamic acid lime juice.
\end{tabular}

The L-ascorbic acid (AA) is the main active form of vitamin $\mathrm{C}$, and it is reversibly oxidized to dehydroascorbic acid, also presenting biological activity (ARANHA et al., 2000). It is widely spread in vegetal cells and has a crucial function in their growth and metabolism (HERNÁDEZ; LOBO; GONZÁLEZ, 2006). The fruit juices, especially citrus juices, are important $A A$ sources (KABASAKALIS; SIOPIDOU; MOSHATOU, 2000), and are synthesized from sugars supplied through photosynthesis (LEE; KADER, 2000). Temperature control is the main postharvest factor to maintain this vitamin concentration, with losses increasing significantly with temperature increase and storage time (LEE et al., 2006). The vitamin C content in fruit and vegetables can be influenced by some factors such as: genotypic differences, pre-harvest conditions, maturity stage, harvest methods, and post-harvest handling system. In citrus, vitamin $\mathrm{C}$ concentration decreases with ripening. However, vitamin $\mathrm{C}$ content is higher in mature fruit than in green fruit because fruit juice volume and fruit size increase in mature fruit. The vitamin C content of citrus juice increases with potassium soil fertilization and decreases with high nitrogen fertilization (LEE et al., 2006).

Morillas Ruiz (2005) observed that ecological crops of tangerines and lemons presented higher antioxidant activity and vitamin $\mathrm{C}$ content than conventional fruit crops. However, the opposite was observed in oranges, in which the conventional crops had higher vitamin $\mathrm{C}$ content than the ecological ones. Additionally, Borguini and Silva (2007) did not find significant differences for the ascorbic acid content in Carmen cultivar tomato samples, cultivated in both organic and conventional crops. On the other hand, for Debora cultivar, the same authors observed a higher ascorbic acid content in conventional tomato crops than in organic tomato crops. Therefore, it is clear that a standard behavior was not identified.

\subsection{Soluble sugars (fructose, glucose, and sucrose)}

The fructose and glucose contents of LB samples were significantly lower than those found in the LC samples $(\mathrm{p}<0.05)$ (Table 1). This can explain the lower soluble solids content in the BL 
juice samples. Many different factors could have contributed to the low soluble sugar content in the LB samples. One of them is mineral fertilization, whereas potassium is the crucial mineral element causing starch accumulation in Citrus leaves (LAVON et al., 1995).

On the other hand, for citrus fruits, delay in the development of dry matter accumulation in the developing fruit increased markedly exceeding the photosynthetic capacity of leaf inflorescence (MARTINEZ-CORTINA; SANZ, 1991). The carbohydrate reserves previously accumulated in the leaves can be mobilized and sucrose levels can decrease showing a limitation in carbohydrate supply.

The shortage of free sugars may trigger ethylene synthesis since defoliation, which drastically reduces sucrose transport to the fruit, increases ethylene synthesis (ORTOLÁ; MONERRI; GUARDIOLA, 2007) and 1-aminocyclopropane-1-carboxylic acid (ACC) accumulation (GÓMEZ-CADENS et al., 2000).

\subsection{Minerals}

Significant differences were observed between the LC and LB groups for calcium $(\mathrm{Ca})$ and zinc $(\mathrm{Zn})$ contents. The conventional lime juice presented higher potassium (K), manganese $(\mathrm{Mn})$, iron $(\mathrm{Fe})$, and copper $(\mathrm{Cu})$ (Table 1).

It can be observed that the $\mathrm{Ca}, \mathrm{K}, \mathrm{Mn}$, and $\mathrm{Zn}$ contents for both samples were rather lower than those reported by the USDA ( UNITED..., 2005). For whole lime juice, these contents were expressed in $\mu \mathrm{g} . \mathrm{g}^{-1}$ as: $140 ; 1170 ; 0.18$; and 0.8 , respectively. On the other hand, the values for $\mathrm{Fe}\left(0.9 \mu \mathrm{g} . \mathrm{g}^{-1}\right)$ and $\mathrm{Cu}\left(0.27 \mu \mathrm{g} \cdot \mathrm{g}^{-1}\right)$ were slightly lower for the LB group than for LC.

These differences can be caused by pesticides/fungicides used in conventional methods, which increase the minerals contents in the soil. The biological activity and $\mathrm{pH}$ of the soil can influence the bioavailability of the minerals (HE; YANG; PETER, 2005). The distribution of minerals in the fruit is also an important factor. Gorinstein et al. (2001) reported significant differences between mineral contents of lemon juice and its peels.

\section{Conclusions}

No significant differences in total titrable acidity, $\mathrm{pH}$, ascorbic acid, sucrose, calcium, and zinc were found between lime juice samples from biodynamic and conventional crops production systems. On the other hand, the organic biodynamic fruit presented lower fructose, glucose, total soluble solids contents, potassium, manganese, iron, and copper as well as higher peel percentage than the conventional lime group producing lower juice yield in the biodynamic crop samples.

Nevertheless, fruit juice from biodynamic crops could be a good choice since it is free from pesticides and other agents that cause problems to human health maintaining the levels similar to those of important nutritional compounds.

\section{Acknowledgements}

The authors are grateful for the financial support provided by The National Council for Scientific and Technological Development (CNPq) and to Embrapa- Food Technology Brazil for the use of the HPLC equipment.

\section{References}

ASSOCIATION OF OFFICIAL ANALYTICAL CHEMISTS - AOAC. Methods of Analysis of the Association of Official Analytical Chemists. 14. ed. Arlington: AOAC, 2005.

ARANHA, F. Q. et al. O papel da vitamina C sobre as alterações orgânicas no idoso. Revista de Nutrição, v. 13, n. 2, p. 89-97, 2000.

BORGUINI, R. G.; SILVA, M. V. O conteúdo nutricional de tomates obtidos por cultivo orgânico e convencional. Higiene Alimentar, v. 21, n. 149, p. 41-46, 2007.

BRASIL. Ministério da Agricultura, Pecuária e Abastecimento. Instrução Normativa $\mathrm{n}^{\circ} 01$, de 7 de Janeiro de 2000. Padrões de Identidade e Qualidade para Suco de Lima Ácida. Diário Oficial da República Federativa do Brasil, Brasília, DF, 10 jan. 2000. Seção I, anexo I, p. 54.

CHINNICI, F. et al. Optimization of the determination of organic acids and sugars in fruits juices by ion-exclusion liquid chromatography. Journal of Food Composition and Analysis, v. 18, p. 121-130, 2005. http://dx.doi.org/10.1016/j.jfca.2004.01.005

CHITARRA, M. I. F.; CHITARRA, A. B. Pós-colheita de frutos e hortaliças: fisiologia e manuseio. Lavras: FAEP, 1990.

FOOD AND AGRICULTURE ORGANIZATION - FAO. Committee on Commodity Problems, Intergovernmental Group on Citrus Fruit, Thirteenth Session. Projections of World Production and Consumption of Citrus to 2010. Havana: FAO, 2003. Disponível em: <www.fao.org>. Acesso em: 23 fev. 2007.

GARCÍA-SANCHEZ, F. et al. Effects of salinity and rate of irrigation on yield, fruit quality and mineral composition of 'Fino 49' lemon. European Journal of Agronomy, v. 19, p. 427-437, 2003.

GIL, J. M.; GRACIA, A.; SÁNCHEZ, M. Market segmentation and willingness to pay for organic products in Spain. International Food and Agribusiness Management, review 3, p. 207-226, 2000. http://dx.doi.org/10.1016/S1096-7508(01)00040-4

GÓMEZ-CADENS, A. et al. Hormonal regulation on fruitlet abscission induced by carbohydrate shortage in Citrus. Planta, v. 210, p. 636643, 2000. http://dx.doi.org/10.1007/s004250050054

GORINSTEIN, S. et al. Comparison of some biochemical characteristics of different citrus fruits. Food Chemistry, v. 74, p. 309-315, 2001. http://dx.doi.org/10.1016/S0308-8146(01)00157-1

HE, Z. L.; YANG, X. E.; PETER, J. S. Trace elements in agroecosystems and impacts on the environment. Journal of Trace Elements in Medicine and Biology, v. 19, p.125-140, 2005. PMid:16325528. http://dx.doi.org/10.1016/j.jtemb.2005.02.010

HERNÁDEZ, Y.; LOBO, M. G.; GONZÁLEZ, M. Determination of vitamin $C$ in tropical fruits: A comparative evaluation of methods. Food Chemistry, v. 96, p. 654-664, 2006. http://dx.doi. org/10.1016/j.foodchem.2005.04.012

INTERNATIONAL FEDERATION OF ORGANIC AGRICULTURE MOVEMENTS - IFOAM. Consumer Preference - Does 'Organic' mean 'Quality'? IFOAM, 2005. Disponível em: <www.ifoam.org>. Acesso em: 24 fev. 2007.

INTERNATIONAL ORGANIZATION OF STANDARDIZATION ISO. Fruit and vegetable products: Determination of soluble solids content - Refractometric method. ISO, 1978. 2173 p.

INTERNATIONAL ORGANIZATION OF STANDARDIZATION - ISO. Fruit and vegetable products: Determination of Titrable Acidity. 2. ed. ISO, 1998. 750 p.

KABASAKALIS, V.; SIOPIDOU, D.; MOSHATOU, E. Ascorbic acid content of commercial fruit juices and its rate of loss upon storage. Food Chemistry, v. 70, p. 325-328, 2000. http://dx.doi.org/10.1016/ S0308-8146(00)00093-5 
LAVON, R. et al. Effect of potassium, magnesium and calcium deficiencies on carbohydrate pools and metabolism in Citrus leaves. Journal of American Society for Horticultural Science, v. 120, p. 54-58, 1995.

LEE, S. K.; KADER, A. A. Preharvest and postharvest factors influencing vitamin $\mathrm{C}$ content of horticultural crops. Postharvest Biology and Technology, v. 20, p. 207-220, 2000. http://dx.doi. org/10.1016/S0925-5214(00)00133-2

LEE, W. C. et al. Optimizing conditions for enzymatic clarification of banana juice response surface methodology (RSM). Journal of Food Engineering, v. 73, p. 55-63, 2006. http://dx.doi.org/10.1016/ S0925-5214(00)00133-2

MARIN, F. R. et al. Changes in nutraceutical composition of lemon juices according to different industrial extraction systems. Food Chemistry, v. 78, p. 319-324, 2002. http://dx.doi.org/10.1016/ S0308-8146(02)00102-4

MARSH, K. B. et al. Perception of flavour in standardized fruit pulps with additions of acids or sugars. Food Quality and Preference, v. 17, p. 376-386, 2006. http://dx.doi.org/10.1016/j. foodqual.2005.04.011

MARTINEZ-CORTINA, C.; SANZ, A. Comparision between the effect of the fruit andexogenous GA3 - applications on source-sink relationships of Citrus sprouts. Annals of Botany, v. 68, p. 143-149, 1991.

MATTHEIS, J. P.; FELLMAN, J. K. Preharvest factors influencing flavor of fresh fruit and vegetables. Postharvest Biology and Technology, v. 15, p. 227-232, 1999. http://dx.doi.org/10.1016/ S0925-5214(98)00087-8
MORILLAS RUIZ, J. M. Capacidad antioxidante, vitamina 236 C y polifenoles de cítricos ecológicos vs convencionales. In: CONGRESSO MADRID: Nutrición Hospitalaria, 1., 2005, Madrid. Anais... Madrid, 2005. v. 10, n. 1.

ORTOLÁ, A. G.; MONERRI, C.; GUARDIOLA, J. L. Fruitlet age and inflorescence characteristics affect the thimming and the increase in fruitlet growth rate induced by auxin applications in Citrus. Acta Horticulturae, v. 463, p. 501-508, 2007.

PEDRÃO, M. R. et al. Estabilidade físico-química e sensorial do suco de limão Tahiti natural e adoçado, congelado. Ciência e Tecnologia de Alimentos, v. 19, n. 2, p. 282-286, 1999.

REIJNTJES, C.; HAVERKORT, B.; WATERS-BAYER, A. Agricultura para o futuro: uma introdução à agricultura sustentável e de baixo uso de insumos externos. Rio de Janeiro: ASPTA, 1994.

SOCIEDADE ANTROPOSÓFICA NO BRASIL - SAB. O que é Antroposofia? 2005. Disponível em: <www.sab.org.br/antrop/ antrop.htm>. Acesso em: 24 fev. 2007.

STRINGHETA, P. C.; MUNIZ, J. N. Alimentos orgânicos: produção, tecnologia e certificação. Viçosa: UFV, 2003.

UNITED STATES DEPARTMENT OF AGRICULTURE - USDA. National Nutrient Database for Standard Reference. 2005. Release 18. Disponível em: <http://www.ars.usda.gov/main/ site_main.htm? modecode=12354500>. Acesso em: 24 fev. 2007. 